\title{
Proceeding
}

Supplementary Issue: Spring Conferences of Sports Science. Costa Blanca Sports Science Events, 19-20 June 2020. Alicante, Spain.

\section{The most effective physical exercise to reduce burnout syndrome in university students}

\author{
YURY ROSALES-RICARDO1 ${ }^{1}$, RAYNIER MONTORO-BOMBÚ2 ${ }^{2}$, JOSÉ P. FERREIRA ${ }^{3}$ \\ ${ }^{1}$ Faculty of Sports Sciences and Physical Education, University of Coímbra, Portugal \\ 2Physical Activity and Sport Pedagogy Course, Faculty of Human Sciences and Education, University of \\ Ambato, Ecuador \\ ${ }^{3}$ Centre of Sports and Physical Activity Research, Faculty of Sports Sciences and Physical Education \\ University of Coímbra, Portugal
}

\begin{abstract}
The objective of this study was to determine the most effective physical exercise in reducing burnout syndrome levels in university students. Methods: An experimental study was carried with 2 intervention groups with aerobic and strength exercise and one control group without exercise. Instruments: Maslach Burnout Inventory Students Survey and Heart Rate Variability (HRV): RR mean, SDNN, and RMSSD. Results: In exhaustion there was the greatest percentage of change in the aerobics group with a reduction of $26 \%$, followed by the strength group (19.5\%). In the cynicism it was the strength group that had the greatest reduction (27\%) over the aerobics group (21\%). Comparison between groups of aerobics and strength: dimension effectiveness low $(d=0.284, P D=10.51 \%)$, in exhaustion and cynicism trivial $(d=$ $0.068, P D=4.83 \%$; and $0.030,3.39 \%)$. In HRV three variables with trivial effect size $(d=0.071,0.85 \%$; $0.177,5.22 \%$ and $0.075,2.95 \%)$. HRV behaved differently: RR mean, the difference was large $(d=0.905$, $10.24 \%)$, in SDNN it was moderate $(d=0.515,14.48 \%)$, whereas in RMSSD it was small. Conclusions: Aerobic exercises were more effective in reducing levels of exhaustion, while strength exercises reduced levels of the cynicism and effectiveness dimensions.

Keywords: Physical exercises; Sports health; Mental health; Burnout syndrome.

Cite this article as:

Rosales-Ricardo, Y., Montoro-Bombú, R. \& Ferreira, J.P. (2020). The most effective physical exercise to reduce burnout syndrome in university students. Journal of Human Sport and Exercise, 15(3proc), S518-S530. doi:https://doi.org/10.14198/jhse.2020.15.Proc3.05
\end{abstract}

\footnotetext{
Corresponding author. Faculty of Sports Sciences and Physical Education, University of Coímbra, Portugal. https://orcid.org/0000-0002-0525-2405

E-mail: yuryrr82@gmail.com

Supplementary Issue: Spring Conferences of Sports Science. Costa Blanca Sports Science Events, 19-20 June 2020. Alicante, Spain.

JOURNAL OF HUMAN SPORT \& EXERCISE ISSN 1988-5202

(c) Faculty of Education. University of Alicante

doi:10.14198/jhse.2020.15.Proc3.05
}

S518 $|2020|$ Proc3 | VOLUME 15

C 2020 University of Alicante 


\section{INTRODUCTION}

Burnout Syndrome (SB) is a health problem of great social repercussion nowadays. The interest currently aroused by the SB has facilitated an expansion of its field of study - which was initially exclusively the domain of health professionals - as research began in many other professional fields and even in university students (Segura, 2014).

When one tries to define SB one can find a multiplicity of definitions in this respect. Currently, most of the studies are framed within the three-dimensional approach that the syndrome is composed of emotional exhaustion, depersonalization and loss of self-fulfilment in the workplace (Martínez-Moreno et al., 2020; Pires and Ugrinowitsch, 2020; Li, et al. 2018; Mikalauskas et al., 2018; Kavanagh et al., 2018; Armenta-Hernández et al., 2018; Bruschini et al., 2018; Kawamura et al, 2017; Leiter and Maslach, 2017) and in the case of students the three dimensions are: emotional exhaustion, cynicism and academic effectiveness or selfefficacy (Liu et al., 2018; Boni et al., 2018; Erschens et al., 2018; Liébana-Presa et al., 2017; HederichMartínez et al., 2016; Tomaschewski et al., 2014) University students, like any professional, are faced with the pressures and overloads of academic work.

Intervention programs to prevent or treat burnout syndrome are essential to improving the health of workers and students. In the absence of an effective program, employees or students are likely to suffer from a job or related mental health deficiency where risk factors prevail. Review studies (Colin et al., 2016; Wendy et al., 2010) have shown that the vast majority of research conducted and found is psychological and cognitive interventions. This is not so with a variety of studies showing the possible benefits of physical exercise in any of its different variants. In addition, whether the most effective type of exercise for treating and preventing this syndrome in the college student population is aerobic or anaerobic (strength) has not been determined.

The practice of regular physical exercise has beneficial effects for the integral health of the human being, in the physical sphere (Comin et al., 2018; Liu et al., 2018; Foright et al., 2018; Wiklund, 2016), mental (Colledge et al., 2018; Alonso-Patiño et al., 2013; Revnic et al., 2013) and socio-affective (Baillot et al., 2018; Rammant et al., 2017; Womble et al., 2014).

To date, very few intervention studies with physical exercise have been conducted in college students with SB. Regular physical exercise may be an effective intervention to reduce burnout levels in workers and students with this harmful syndrome, but it has not been correctly defined what type of exercise is most effective in treating and preventing SB, whether it is aerobic or anaerobic (strength).

Therefore, the objective of this study was to determine the most effective physical exercise in reducing burnout syndrome levels in university students.

\section{MATERIALS AND METHODS}

\section{Study design}

An experimental study was carried out with pre-test and post-test, with 2 intervention groups (aerobic exercise group of 26 and strength exercise group of 25) and one control group (without exercise of 27). The participants in each group were randomly distributed, using a simple random sampling. 


\section{Participants}

The sample was identified from the population of students diagnosed with burnout syndrome at the University of Ambato in Ecuador, where a wide variety of university degrees (in health sciences, engineering, education sciences, economics and business, agronomy, law, tourism and social sciences) will be studied. The sample was probabilistic and a stratified sample with proportional participation was used. In the case of medical students, the sixth year or internship is excluded, since at this stage students are considered more workers than students because of the characteristics of this academic year.

First, a stratified random sample was selected from the student population of the University of Ambato, Ecuador, to which the exposed diagnostic instruments were applied (n1). After the students who are diagnosed with moderate or high levels of BS a sample was selected by simple random sampling (n2). Finally, from this last sample, the following was selected: a sample randomly assigned to the 3 groups of the quasiexperiment study (n3) (see figure I).

\section{Measures}

Burnout syndrome in students

The Maslach Burnout Inventory Students Survey (MBI-SS) (Schaufeli et al., 2002). will be used. It is structured in 3 dimensions divided into 15 items: Emotional exhaustion, Cynicism and Academic Effectiveness. The response scale is Likert type and ranges from 0 ("never") to 6 ("always").

Heart Rate Variability (HRV)

Using a transmitter band and the Elite HVR android application and calculating RR mean (interval mean RR), SDNN (standard deviation of the periods NN), y RMSSD (square root of the mean value of the sum of the squared differences of all successive RR intervals).

\section{Procedures and intervention}

After knowing the number of students diagnosed with burnout with the MBI-SS, the heart rate variability (HRV) was measured using a transmitter band and the Elite HVR android application. From there begins the application of the physical exercise programs. They were divided into three groups of similar composition. A control group to which no activity was applied, an experimental group 1 to which aerobic exercise (jogging, walking and/or stationary bicycle for approximately 30 to 50 minutes, divided into an initial part of warm-up and stretching, a main part with planned aerobic exercise and a final part of recovery.) will be applied and an experimental group 2 to which anaerobic (strength) exercise (hands-free exercises such as push-ups, situps, fixed bar, leg squats, with 30 to 50 minute sessions divided into warm-up and stretching parts, main part with planned strength exercises and final part of recovery) will be applied.

According to some studies, HVR is the main cardiovascular biomarker for the prevention and early detection of SB (Maya et al., 2016; Gómez-Alcaina et al., 2013), a non-invasive measure of autonomic influence on heart rate, which has been successfully used to estimate autonomic tone modulation. HVR has become an important risk assessment tool: reduced HVR is associated with poorer prognosis for a wide range of clinical conditions, whereas robust periodic changes in the R-R range are often a health-associated characteristic. In general, lower HVR is seen in participants with occupational stress compared to participants in control groups. In particular, studies appear to confirm that burnout is associated with lower HVR compared to healthy participants (Díaz-Rodríguez et al., 2011; Chandola et al., 2010).

In both intervention groups, physical exercise was governed by the latest guidelines for prescribing exercise (Quantity and quality of exercise to develop and maintain cardiorespiratory, musculoskeletal and neuromotor 
fitness in apparently healthy adults: A Guide to Prescribing Exercise of the American College of Sports Medicine (Garber et al., 2011) and 3 weekly sessions will be applied for one hour, on alternating days, for 16 weeks.

The physical exercises were applied in the sports areas of the University, by a single instructor qualified and trained for that purpose, with a bachelor's degree in physical activity and sports.

In week 17 the same MBI-SS and HRV measurement instruments will again be applied to the 3 groups and longitudinal and cross-sectional comparisons was made. See flow chart (Figure 1).

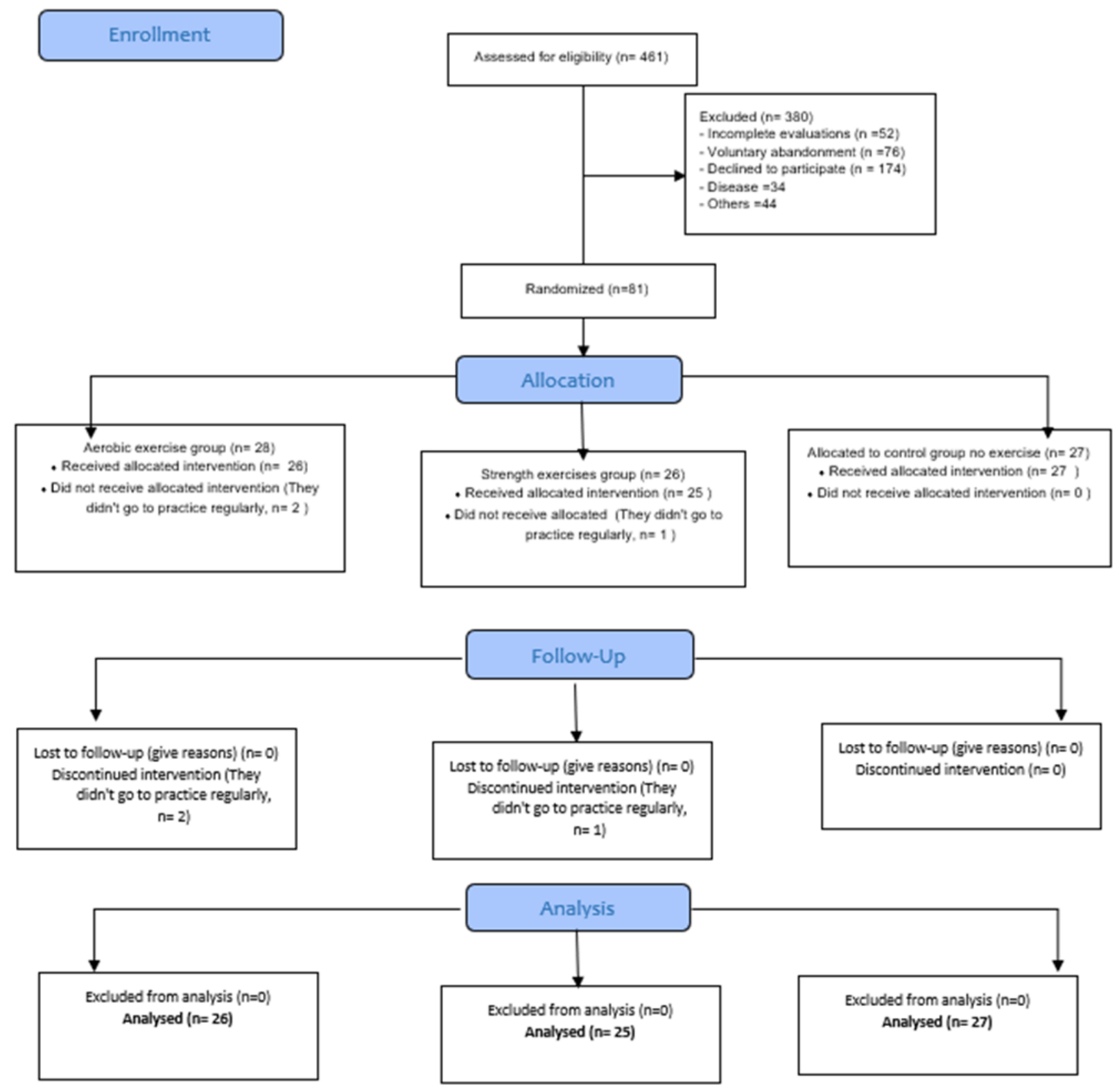

Figure 1. CONSORT flowchart of the study protocol. 


\section{Aerobic exercises}

A frequency of 3 or more days was applied for the week of moderate exercise.

Moderate and/or vigorous intensity for most students. In a time of 30 to 60 minutes per day (150 minutes $x$ week) of intentional moderate exercise. Involving the major muscle groups and continuously and rhythmically in their nature. Increasing the number of steps by 2000 steps per day to achieve and maintain a daily 7000 step number (Garber et al., 2011).

In our study, aerobic exercises were performed (jogging, walking and/or stationary bicycling for approximately 30 to 50 minutes, divided into an initial warm-up and stretching part, a main part with planned aerobic exercises and a final recovery part.

\section{Strength exercises}

Each muscle group was trained 2 to 3 days a week. With an intensity of $60 \%-70 \%$ of $1 \mathrm{RM}$ (moderate to hard intensity) for beginners to intermediate to improve strength. With exercises involving each of the major muscle groups. Using a variety of exercise equipment and/or body weight to perform these exercises. 8 to 12 repetitions to improve strength and power. With 2-3-minute rest intervals between each set of repetitions. And a 48-hour rest between sessions for each muscle group. With a gradual progression of greater endurance, and/or more repetitions per cast, and/or an increasing frequency (Garber et al., 2011).

In our study, strength exercises were applied (hands-free exercises such as push-ups, abdominals, sit-ups, fixed bar, leg squats, with 30 to 50-minute sessions divided into warm-up and stretching parts, the main part with planned strength exercises and the final part of recovery).

\section{Statistical analysis}

All the data collected was analysed using the SPSS "Statistical Package for the Social Sciences, version 25.0 for Windows" software. Descriptive statistics include mean, standard deviation, effect size (d), P value (p) and percentage calculation. Using different statistical methods.

Descriptive statistics are presented using the mean $(X)$ and standard deviation (SD). The normal distribution was tested using the Shapiro-Wilk test. Initial comparisons between groups were made using Kruskal-Wallis tests. Within-group comparisons between the previous and subsequent moments were made using Wilcoxon's signed classification test for Likert scale instruments and physiological (HRV) tests. A t-test for paired samples was used to verify changes in fitness parameters after interventions. The percentage change (job value/previous value] - 1) was calculated and presented for each variable. To report the magnitude of the changes, the size of the effect of the biserial point correlation ( $\mathrm{rpb}$ ) was calculated and converted to the standardized Cohen's $d$. The effect of the biserial point correlation $(\mathrm{rpb})$ was calculated. The reference points used were: trivial $(d<0.2)$, small ( $d=0.2$ to 0.5$)$, moderate $(d=0.5$ to 0.8$)$, large $(d=0.8$ to 1.2$)$, very large $(d>1.2)$ (Cohen, 1988). The level of statistical significance for $p<.05$ was assumed. The Social Sciences Statistical Program (SPSS), version 23.0 for Windows, was used.

\section{Ethics in research}

The planning of this research was carried out taking into account the guidelines of the Declaration of Helsinki of 1973, revised in 1986 and amended in October 2013, and was also governed by the standard regulations in force in the Republic of Ecuador for the conduct of biological studies. 
Students will be explained what the research consists of in order to obtain informed consent to participate in the research and a document will be signed by both the patients and the research author for the record. The study was approved by the corresponding ethics committee, with the code: CEISHSOLCAQ.OBS.19.129.

\section{RESULTS}

\section{Baseline characteristics}

The basic characteristics of the participants in each of the two conditions are found in Table 1. There were no differences between the conditions at the beginning of the study. The participants were recruited to make up the three groups according to the initial diagnosis using the MBI-SS, with a majority of the female sex (11 $/ 17,10 / 16$ and $12 / 15)$ and in both sexes an average between 22 and 23 years.

The flow chart of the participants is shown in Figure 1. The aerobic exercise group consisted of 28 students (age: $22.74 \pm 3.05$ ), all received the intervention, although for statistical analysis only 26 were taken into account since 2 did not perform a regular practice of at least 3 days per week. The group of strength exercises consisted of 26 students (22.97 \pm 3.31 ), all also received regular intervention, although only 25 were taken into account for statistical analysis as one did not regularly perform the practices. On the other hand, the control group, which did not receive any intervention but was followed up, consisted of 27 students (23.13 \pm 3.77). In the latter, there was no statistical loss.

\section{The most effective type of exercise to treat $S B$}

In the comparison between the final tests of the groups of aerobics and strength in terms of their size of effect it was possible to prove that except for the dimension effectiveness that was low $(d=0.284$, percent difference between both groups $P D=10.51 \%)$, in the other two dimensions exhaustion and cynicism were trivial $(d=$ $0.068, P D=4.83 \%$; and $0.030,3.39 \%)$. In the case of $\mathrm{HRV}$ its three variables were rated with a trivial effect size ( $d=0.071,0.85 \% ; 0.177,5.22 \%$ and $0.075,2.95 \%$ ) (see table 2 ). As for the comparison between the final tests of the control groups and the aerobics the dimensions exhaustion and efficacy showed a small difference $(d=0.374,25.43 \%$ and $0.486,16.82 \%)$ and in cynicism it was trivial $(0.165,19.35 \%)$. HRV behaved differently: In RR mean the difference was remarkably large $(d=0.905,10.24 \%)$, in SDNN it was moderate $(d=0.515,14.48 \%)$, whereas in RMSSD it was small. There was only a small difference between the results of the intervention in both groups according to the MBI-SS. On the other hand, according to the $\mathrm{HRV}$ in general, the difference was much greater and could be qualitatively qualified as moderately large (see table 2). In the comparison between the control group and the strength group, the differences to the previous group were different. The efficiency dimension had moderately high differences $(\mathrm{d}=0.783,25.56 \%)$, on exhaustion and cynicism where they were small and trivial respectively $(d=0.306,21.65 \%$ and 0.131 , $16.52 \%)$. According to HRV the differences were large, small and trivial according to RR MEAN, SDNN and RMSSD ( $d=0.872,9.48 \% ; 0.347,9.77 \%$ and $0.195,7.67 \%$ respectively). There was a difference between both groups, although relatively small according to the MBI-SS and moderate in terms of HRV (see Table 1).

The differences found between the pre-test and post-test groups can also be seen in Table 2. In the exhaustion dimension there was the greatest percentage of change in the aerobics group with a reduction of $26 \%$, followed by the force group (19.5\%). In the cynicism dimension it was the force group that had the greatest reduction (27\%) over the aerobics group (21\%). Something similar happened in the effectiveness dimension, the force group in this case the difference was $21 \%$ against $13 \%$ of the aerobics group. 
Table 1. Comparison between experimental groups and the control group between them

\begin{tabular}{|c|c|c|c|c|c|c|c|c|c|c|c|c|}
\hline \multicolumn{5}{|c|}{ A } & \multicolumn{4}{|c|}{ B } & \multicolumn{4}{|c|}{ C } \\
\hline & $\begin{array}{c}\text { POST GE } \\
\text { AEROB } \\
\text { MEAN (SD) }\end{array}$ & $\begin{array}{l}\text { POST GE } \\
\text { STRENGTH } \\
\text { MEAN (SD) }\end{array}$ & $\begin{array}{l}\text { PERCENT } \\
\text { DIF }\end{array}$ & $\begin{array}{l}\text { EFFECT } \\
\text { SIZE (d) }\end{array}$ & $\begin{array}{l}\text { POST } \\
\text { GC } \\
\text { MEAN } \\
\text { (SD) }\end{array}$ & $\begin{array}{c}\text { POST GE } \\
\text { AERO } \\
\text { MEAN } \\
\text { (SD) }\end{array}$ & $\begin{array}{l}\text { PERCENTAGE } \\
\text { DIFFERENCE }\end{array}$ & $\begin{array}{l}\text { EFFECT SIZE } \\
\text { (d) }\end{array}$ & $\begin{array}{c}\text { POST GC } \\
\text { MEAN } \\
\text { (SD) }\end{array}$ & $\begin{array}{l}\text { POST GE } \\
\text { STRENGTH } \\
\text { MEAN (SD) }\end{array}$ & $\begin{array}{l}\text { PERCENT } \\
\text { DIFF }\end{array}$ & $\begin{array}{l}\text { EFFECT } \\
\text { SIZE (d) }\end{array}$ \\
\hline Exhaustion & $\begin{array}{c}1.38 \pm \\
0.99\end{array}$ & $\begin{array}{c}1.45 \pm \\
1.11\end{array}$ & 4.83 & 0.068 & $\begin{array}{c}1.85 \pm \\
1.31\end{array}$ & $\begin{array}{c}1.38 \pm \\
0.99\end{array}$ & 25.43 & 0.374 & $\begin{array}{c}1.85 \pm \\
1.31\end{array}$ & $\begin{array}{c}1.45 \pm \\
1.11\end{array}$ & 21.65 & 0.306 \\
\hline Cynicism & $\begin{array}{c}0.93 \pm \\
0.97\end{array}$ & $\begin{array}{c}0.96 \pm \\
1.22\end{array}$ & 3.39 & 0.030 & $\begin{array}{c}1.15 \pm \\
1.69\end{array}$ & $\begin{array}{c}0.93 \pm \\
0.97\end{array}$ & 19.35 & 0.165 & $\begin{array}{c}1.15 \pm \\
1.69\end{array}$ & $\begin{array}{c}0.96 \pm \\
1.22\end{array}$ & 16.52 & 0.131 \\
\hline Efficacy & $\begin{array}{c}3.71 \pm \\
1.49\end{array}$ & $\begin{array}{c}3.32 \pm \\
1.29\end{array}$ & 10.51 & 0.284 & $\begin{array}{c}4.46 \pm \\
1.65\end{array}$ & $\begin{array}{c}3.71 \pm \\
1.49\end{array}$ & 16.82 & 0.486 & $\begin{array}{c}4.46 \pm \\
1.65\end{array}$ & $\begin{array}{c}3.32 \pm \\
1.29\end{array}$ & 25.56 & 0.783 \\
\hline $\begin{array}{l}\text { RR Mean } \\
\text { (ms): }\end{array}$ & $\begin{array}{c}1011.37 \pm \\
128.32\end{array}$ & $\begin{array}{c}1002.77 \pm \\
117.92\end{array}$ & 0.85 & 0.071 & $\begin{array}{c}907.72 \pm \\
104.05\end{array}$ & $\begin{array}{c}1011.37 \\
\pm 128.32\end{array}$ & 10.24 & 0.905 & $\begin{array}{c}907.72 \pm \\
104.05\end{array}$ & $\begin{array}{c}1002.77 \pm \\
117.92\end{array}$ & 9.48 & 0.872 \\
\hline SDNN & $\begin{array}{c}94.87 \pm \\
29.86\end{array}$ & $\begin{array}{c}89.92 \pm \\
27.24\end{array}$ & 5.22 & 0.177 & $\begin{array}{c}81.13 \pm \\
24.27\end{array}$ & $\begin{array}{c}94.87 \pm \\
29.86\end{array}$ & 14.48 & 0.515 & $\begin{array}{c}81.13 \pm \\
24.27\end{array}$ & $\begin{array}{c}89.92 \pm \\
27.24\end{array}$ & 9.77 & 0.347 \\
\hline RMSSD & $\begin{array}{c}82.24 \pm \\
33.78\end{array}$ & $\begin{array}{c}79.81 \pm \\
32.73\end{array}$ & 2.95 & 0.075 & $\begin{array}{c}73.69 \pm \\
31.39\end{array}$ & $\begin{array}{c}82.24 \pm \\
33.78\end{array}$ & 10.39 & 0.267 & $\begin{array}{c}73.69 \pm \\
31.39\end{array}$ & $\begin{array}{c}79.81 \pm \\
32.73\end{array}$ & 7.67 & 0.195 \\
\hline
\end{tabular}

$p<.05$; comparison using compared using Wilcoxon signed rank test. A: Comparison between aerobic and strengths group posttests; $B$ : Comparison between control and aerobic group posttests; C: Comparison between control group and strengths group posttests. RR mean = mean of the RR intervals; SDNN = standard deviation of the NN (or RR) periods; $R M S S D=$ square root of the mean value of the sum of the square differences of all successive RR intervals

Table 2. Comparison between pre and post exercise interventions and control group (no exercise intervention) with MBI-SS results.

\begin{tabular}{|c|c|c|c|c|c|c|c|c|c|}
\hline \multicolumn{4}{|c|}{ GE AEROBICS $(n=26)$} & \multicolumn{3}{|c|}{ GE STRENGTH $(n=25)$} & \multicolumn{3}{|c|}{$G C(n=27)$} \\
\hline SB DIMENSIONS & $\begin{array}{c}\text { PRE } \\
\text { MEAN } \\
(\mathrm{SD}) \\
\end{array}$ & $\begin{array}{c}\text { POST } \\
\text { MEAN (SD) }\end{array}$ & $\begin{array}{l}\text { PERCENT } \\
\text { CHANGE }\end{array}$ & $\begin{array}{c}\text { PRE } \\
\text { MEAN } \\
(\mathrm{SD}) \\
\end{array}$ & $\begin{array}{c}\text { POST } \\
\text { MEAN } \\
(\mathrm{SD}) \\
\end{array}$ & $\begin{array}{l}\text { PERCENT } \\
\text { CHANGE }\end{array}$ & $\begin{array}{c}\text { PRE } \\
\text { MEAN } \\
\text { (SD) }\end{array}$ & $\begin{array}{c}\text { POST } \\
\text { MEAN } \\
(\mathrm{SD}) \\
\end{array}$ & $\begin{array}{l}\text { PERCENT } \\
\text { CHANGE }\end{array}$ \\
\hline Exhaustion & $\begin{array}{c}2.00 \pm \\
1.24\end{array}$ & $\begin{array}{c}1.38 \pm \\
0.99\end{array}$ & -26.4 & $\begin{array}{c}1.80 \pm \\
1.19\end{array}$ & $\begin{array}{c}1.45 \pm \\
1.11\end{array}$ & -19.55 & $\begin{array}{c}1.68 \pm \\
1.27\end{array}$ & $\begin{array}{c}1.85 \pm \\
1.31\end{array}$ & 10.26 \\
\hline Cynicism & $\begin{array}{c}1.18 \pm \\
1.03\end{array}$ & $\begin{array}{c}0.93 \pm \\
0.97\end{array}$ & -21.06 & $\begin{array}{c}1.32 \pm \\
1.12\end{array}$ & $\begin{array}{c}0.96 \pm \\
1.22\end{array}$ & -27.38 & $\begin{array}{c}1.24 \pm \\
1.22\end{array}$ & $\begin{array}{c}1.15 \pm \\
1.69\end{array}$ & -7.26 \\
\hline Efficacy & $\begin{array}{c}4.27 \pm \\
1.38\end{array}$ & $\begin{array}{c}3.71 \pm \\
1.49\end{array}$ & -13.11 & $\begin{array}{c}4.24 \pm \\
1.37\end{array}$ & $\begin{array}{c}3.32 \pm \\
1.29\end{array}$ & -21.69 & $\begin{array}{c}4.27 \pm \\
1.34\end{array}$ & $\begin{array}{c}4.46 \pm \\
1.65\end{array}$ & 4.26 \\
\hline
\end{tabular}

$p<.05$; comparison using compared using Wilcoxon signed rank test. 


\section{DISCUSSION}

The objective of this study was to determine the most effective physical exercise in reducing burnout syndrome levels in university students: whether it is aerobic or anaerobic (strength). The results show that there is no significant difference between the intervention with both types of exercise, according to MBI-SS and HRV.

In our study we were able to define that depending on the dimension in which we intervene, the type of exercise to be applied could be more or less effective. That is, at least according to our results, aerobic exercises were more effective in reducing levels of exhaustion, while strength exercises reduced levels of the cynicism and effectiveness dimensions of SB by a greater percentage. So, we have to see the SB as a complex and in this case three-dimensional construct.

That is to say, there could be a moderately small improvement in general among the members of the intervention groups with aerobic and strength exercises over those of the control group. These results coincide with those found in the previous comparison. In other words, the differences between aerobic and strength exercise intervention could be insignificant, and this may depend on which dimension of the SB has higher levels.

This study could have an important practical significance since, from its results, more personalized physical exercise programs could be elaborated, proposed and validated according to the general levels of SB, also the specific levels of each dimension that composes the syndrome in the case of university students.

Some previous studies show similar results and others not so much, or even different results. As can be seen in the following by Han et al. (2013), that explored the effectiveness of an exercise program for bank and insurance workers with BS. High intensity group had greater improvements of pre-and post-exercise difference for the indicators of personal burnout and work-related burnout. Exercise intensity was considered as a factor that effects the variations of job strain indicators. The exercise program releases the tension of personal and work-related burnout decreased significantly with exercise intensity. Exercise intensity modified the effect of work-related burnout difference. Therefore, and it have suggested that exercise intensity has a significant effect in the relationship between burnouts and systolic blood pressure in short-term exercise program. In this study, the effects of the exercise program are shown significant in several areas, with improvements in burnouts.

In other study conducted by Bretland and Thorsteinsson (2015), with participants from the Tamworth and Armidale locality of New England workers and students, Australia. The cardiovascular and resistance conditions both showed significantly greater positive well-being than the control condition but were comparable to each other. The cardiovascular condition tended to reduce emotional exhaustion as compared to the control condition. Cardiovascular and resistance conditions were comparable in measured decrease in perceived stress, and emotional exhaustion. Additional exercise in excess of the minimum recommended standards may lead to further gains in positive well-being, perceived stress, and emotional exhaustion, based on correlational analysis of the change over four weeks and hours of exercise conducted.

De Vries et al. (2016) study, analysed the extent to which an exercise intervention is effective in reducing BS indicators in students. The participants in the intervention group showed a greater decrease in BS levels in a general way. These results highlight the value of low intensity exercise for college students with a high level of BS related to the study. Participants in the intervention group showed a greater BS decrease $(t(48)=6.82$; 
$p=<.001$; Cohen's $d=0.90$ ) than those of the control group (t $(47)=3.08, p=.003$; Cohen's $d=0.46)$. A little higher than our case where the intervention group with aerobic exercises through the main dimension exhaustion the size of the effect was slightly lower $(d=0.532)$, and even lower the group with strength exercises. $(d=0.299)$ and the control group $(d=0.128)$. These results underline the value of low-intensity exercise for university students with high levels of study-related fatigue. As well as the one made by Eskilsson et al. (2017), applied an aerobic training program performed at a moderate-vigorous intensity for BS patients. The patients were randomized into two groups, one intervention group with 12-week aerobic exercise and a control group without additional training. In the final evaluation, a decrease in BS levels was reported in the intervention group (pretest: $4.75(0.98)$, posttest: $3.92(1.10))$, while in the control group the decrease in the BS level was much lower (pretest: 4.84 (1.01), (posttest: $4.40(1.08)$ ); $F(1.54)=2.82$, p-value $=.10 ; \eta p 2=$ .05 . Since the averages of these results are higher than those found in our study, even though in general the three results are similar in the reduction of SB levels through exercise.

Among the possible strengths of this study are the correct methodology used in the investigation to determine its results when carried out in three groups, one of them control, made at random of very similar structure with initial test and final test. In addition, the exercises were applied in the intervention groups following the latest recommendations of the ACSM.

On the other hand, regarding limitations it could be stated that it was not possible to apply other tests related to the hypothalamus-hypophysis-suprarenal and sympathetic-medulus-suprarenal axes, related to the immune system and those related to inflammation (Gómez-Alcaina et al., 2013). In order to determine the effectiveness of the application of physical exercises, psychological cut test and cardiovascular cut test were used instead. Despite the fact that the latter are validated nationally and internationally, and have a wellproven efficacy, it would have been interesting to be able to also apply the former for a better evaluation and strength of the results.

According to the results shown above of this study there were differences between the initial and final tests in the three groups, but in the two intervention groups with aerobic and strength exercises the difference was greater than in the control group in terms of the results of the application of MBI-SS and HRV in terms of the reduction of SB levels.

For future studies, more specific exercise programs for the reduction of SB levels in university students could be developed, proposed and validated, depending on the dimension of the syndrome that really needs to be treated the most, and this could be the type of exercise that would be applied or at least that would prevail in these programs.

\section{CONCLUSIONS}

In our studio, in general, there were no significant differences between the results of the intervention in the aerobic and strength groups according to MBI-SS and HRV. The differences between aerobic and strength exercise intervention could be insignificant. It could depend on the dimension in which we intervene, the type of exercise to be applied could be more or less effective. And aerobic exercises were more effective in reducing levels of exhaustion, while strength exercises reduced levels of the cynicism and effectiveness dimensions of SB by a greater percentage. 


\section{REFERENCES}

Alonso-Patiño F., Villada E., Arango-Vélez F., Zuleta-Baena L. (2013). Ejercicio físico y depresión en adultos mayores: una revisión sistemática. Rev. Col. Psiquiatría, 42(2), 198-211. https://doi.org/10.1016/S0034-7450(13)70007-6

Armenta-Hernández, O.D., Maldonado-Macías, A., García-Alcaraz, J., Avelar-Sosa, L., and SerranoRosa M.A. (2018). Relationship between Burnout and Body Mass Index in Senior and Middle Managers from the Mexican Manufacturing Industry. Int J Environ Res Public Health, 15(3). https://doi.org/10.3390/ijerph15030541

Baillot, A., Saunders, S., Brunet, J., Ahmed, J., Romain, A. and Bernard, B. (2018). A systematic review and meta-analysis of the effect of exercise on psychosocial outcomes in adults with obesity: A call for more research. Mental Health and Physical Activity, 14, 1-10. https://doi.org/10.1016/..mhpa.2017.12.004

Boni, R.A.S., Paiva, C.E., de Oliveira, M.A., Lucchetti, G., Fregnani, J.H.T. and Paiva, B.S.R. (2018) Burnout among medical students during the first years of undergraduate school: Prevalence and associated factors. PLoS ONE, 13(3), e0191746. https://doi.org/10.1371/journal.pone.0191746

Bradley, M. T., Best, L. A. and Stoica, G. (2008). Accuracy of Effect Size Estimates from Published Psychological Research. Perceptual and Motor Skills, 106, 645-649. https://doi.org/10.2466/pms.106.2.645-649

Bretland, R.J., Thorsteinsson, E.B. (2015). Reducing workplace burnout: the relative benefits of cardiovascular and resistance exercise. PeerJ, 9(3): e891. https://doi.org/10.7717/peeri.891

Bruschini, M., Carli, A. and Burla, F. (2018). Burnout and work-related stress in Italian rehabilitation professionals: A comparison of physiotherapists, speech therapists and occupational therapists. Work, 59(1), 121-129. https://doi.org/10.3233/WOR-172657

Chandola, T., Heraclides, A., y Kumari, M. (2010). Psychophysiological biomarkers of workp lace stressors. Neuroscience and Biobehavioral Reviews, 35, 51-57. https://doi.org/10.1016/i.neubiorev.2009.11.005

Cohen, J. (1988). Statistical Power Analysis for the Behavioral Sciences, 2nd edition. Erlbaum, Hillsdale, NJ.

Colin, P.W., Liselotte, N.D., Patricia, J.E. and Tait, D.S. (2016). Interventions to prevent and reduce physician burnout: a systematic review and meta-analysis. Lancet, 5, 388 (10057), 2272-2281. https://doi.org/10.1016/S0140-6736(16)31279-X

Colledge, F., Brand, S., Pühse, U., Holsboer-Trachsler, E., Zimmerer, S., Schleith, R. and Gerber, M.A. (2018). Twelve-Week Moderate Exercise Programme Improved Symptoms of Depression, Insomnia, and Verbal Learning in Post-Aneurysmal Subarachnoid Haemorrhage Patients: A Comparison with Meningioma Patients and Healthy Controls. Neuropsychobiology, 25, 1-13. https://doi.org/10.1159/000486903

Comin, J., Aquino-Junior, J., MacKenzie, B.A., Almeida-Oliveira, A.R., Martins, A.C., Osorio-Leiria, L.,... and Abdalla, M.J. (2018). Aerobic exercise inhibits obesity-induced respiratory phenotype. Cytokine, 104, 46-52. https://doi.org/10.1016/i.cyto.2017.12.025

De Vries JD, van Hooff MLM, Geurts SAE, Kompier MAJ. (2016). Exercise as an Intervention to Reduce Study-Related Fatigue among University Students: A Two-Arm Parallel Randomized Controlled Trial. PLOS ONE. ;11(3): e0152137. https://doi.org/10.1371/journal.pone.0152137

Díaz-Rodríguez, L., Arrollo-Morales, M., Fernández-de las- Peñas, C., García-Lafuente, F., GarcíaRoyo, C., y Tomás-Rojas, I. (2011). Immediate effects of reiki on heart rate variability, cortisol levels, and body temperatura in health care professionals with burnout. Bilogogical Research For Nursing, 13, 376-382. https://doi.org/10.1177/1099800410389166 
Erschens, R., Keifenheim, K.E., Herrmann-Werner, A., Loda, T., Schwille-Kiuntke, J., Bugaj, T.J.,...Junne, F. (2018). Professional burnout among medical students: Systematic literature review and meta-analysis. Med Teach, 14, 1-12. https://doi.org/10.1080/0142159X.2018.1457213

Eskilsson, T., Slunga, L.J., Malmberg, H.G., Stigsdotter, A.N. and Boraxbekk, C.J. (2017). Aerobic training for improved memory in patients with stress-related exhaustion: a randomized controlled trial. BMC Psychiatry, 17, 322. https://doi.org/10.1186/s12888-017-1457-1

Fernandes, H. M. (2018). Physical activity and mental health in adolescents: The mediating effect of selfesteem and body satisfaction. Revista de psicologia del deporte, 27(1), 67-76.

Foright, R.M., Presby, D.M., Sherk, V.D., Kahn, D., Checkley, L., Giles, E.D., ...Mac-Lean, P.S. (2018). Is regular exercise an effective strategy for weight loss maintenance? Physiology \& Behavior, 188, 86-93. https://doi.org/10.1016/i.physbeh.2018.01.025

Garber, C.E., Blissmer, B., Deschenes, M.R., Franklin, B.A., Lamonte, M.J., Lee, I.M., ... and Swain, D.P. (2011). American College of Sports Medecine position stand. Quantity and quality of exercise to develop and maintain cardiorespiratory, musculoskeletal and neuromotor fitness in apparently healthy adults: A Guide to Prescribing Exercise. Medicine and science in sports and exercise, 43(7), 1334-1359. https://doi.org/10.1249/MSS.0b013e318213fefb

Gerber, M., Ingibj€org, H., Jonsdottir, E.A., Lindwall, M. and Lindegard, A. (2015). Promoting graded exercise as a part of multimodal treatment in patients diagnosed with stress-related exhaustion. Journal of Clinical Nursing, 24, 1904-1915. https://doi.org/10.1111/jocn.12820

Gómez-Alcaina, B.J., Montero-Marín, M.M.P., Demarzo, J.P. and García-Campayo, J. (2013). Utilidad de los marcadores biológicos en la detección precoz y prevención del síndrome de burnout. Rev. Psicopatolog.Psicolog. Clín, 18(3), 245-253. https://doi.org/10.5944/rppc.vol.18.num.3.2013.12924

Han, H.T., Ching, Y.Y., Chien, T.S., Chiou, J.C., Shu, M.P. and Ruey, Y.C. (2013). The Effects of Exercise Program on Burnout and Metabolic Syndrome Components in Banking and Insurance Workers. Industrial Health, 51(3), 336-346. https://doi.org/10.2486/indhealth.2012-0188

Hederich-Martínez CH, Caballero-Domínguez CC. (2016). Validación del cuestionario Maslach Burnout Inventory-Student Survey (MBI-SS) en contexto académico colombiano. Revista CES Psicología, 9 (1): 1-15. https://doi.org/10.21615/cesp.9.1.1

Kavanagh, K.R. and Spiro, J. (2018). Faculty Wellness: Educator Burnout among Otolaryngology Graduate Medical Educators. Otolaryngol Head Neck Surg, 158(4), 1-19. https://doi.org/10.1177/0194599818770647

Kawamura, Y., Takayashiki, A., Ito, M., Maeno, T., Seo, E. and Maeno, T. (2018). Stress Factors Associated With Burnout Among Attending Physicians: A Cross-Sectional Study. J Clin Med Res, 10(3), 226-232. https://doi.org/10.14740/jocmr3299w

Ledezma, Y.S.R., Vega, D.M., Pérez, J.E.P. and Luján, J.C.B. (2017). Actividad física, autoconcepto físico y bienestar psicológico en estudiantes universitarias mexicanas. Revista de Psicología del Deporte, 26(2), 61-69. Retrieved from: https://www.redalyc.org/articulo.oa?id=2351/235152045009

Leiter M. y Maslach C. (2017). Burnout and engagement: Contributions to a new vision. Burnout Research.; 5: 55-57. https://doi.org/10.1016/..burn.2017.04.003

Li, H., Cheng, B. and Zhu, X.P. (2018). Quantification of burnout in emergency nurses: A systematic review and meta-analysis. Int Emerg Nurs, 17, pii, S1755-599X (17)30173-8. https://doi.org/10.1016/i.ieni.2017.12.005

Liébana-Presa, C., Fernández-Martínez, E. and Morán-Astorga, C. (2017). Relación entre la inteligencia emocional y el burnout en estudiantes de enfermería. Psychology, Society, \& Education, 9(3), 335345. https://doi.org/10.25115/psye.v9i3.856 
Liu, H., Yansane, A.I., Zhang, Y., Fu, H., Hong, N. and Kalenderian, E. (2018). Burnout and study engagement among medical students at Sun Yat-sen University, China: A cross-sectional study. Medicine (Baltimore), 97(15), e0326. https://doi.org/10.1097/MD.0000000000010326

Martínez-Moreno, A., Ibáñez-Pérez, R., \& Sánchez-Roca, C. (2020). Leadership, stress and burnout among basketball referees. Journal of Human Sport and Exercise, in press. https://doi.org/10.14198/hhse.2021.161.08

Maya, R.W., Gregory S. Seiberta, A., Sanchez-Gonzalez, F.D. (2016). Physiology of school burnout in medical students: Hemodynamic andautonomic functioning. Burnout Research 3, 63-68. https://doi.org/10.1016/i.burn.2016.05.001

Mikalauskas, A., Benetis, R., Širvinskas, E., Andrejaitienè, J., Kinduris, Š., Macas, A. and Padaiga, Ž. (2018). Burnout Among Anesthetists and Intensive Care Physicians. Open Med (Wars), 5(13), 105112. https://doi.org/10.1515/med-2018-0017

Pires, D.A. and Ugrinowitsch, H. (2020). Burnout and coping perceptions of judo athletes throughout a sport season. Journal of Human Sport and Exercise, in press. https://doi.org/10.14198/jhse.2021.164.10

Rammant, E., Decaestecker, K. and Bultijnck, R. (2017). A systematic review of exercise and psychosocial rehabilitation interventions to improve health-related outcomes in patients with bladder cancer undergoing radical cystectomy. Clinical Rehabilitation, 1-13. https://doi.org/10.1177/0269215517746472

Revnic FG, Prada GII, Pena CM, Prada SP, Revnic CRS. (2013). The role of physical training in management of endocrine modulation, depresion and sexual function in elderly men. European Psychiatry.; 28(1), 1. https://doi.org/10.1016/S0924-9338(13)76910-4

Reynaga-Estrada, P., Robles, D.A.M., Jiménez, A.V., Villalobos, A.R. and Hernández, J.G. (2017). Burnout syndrome in Mexican university sportmen. Revista de Psicologia del Deporte, 26(4), 209214. Retrieved from: https://www.rpd-online.com/article/view/v26-n4-reynaga-estrada-mena-etal

Schaufeli, W.B., Martínez, I.M., Marques-Pinto, A., Salanova, M. and Bakker, A.B. (2002). Burnout and engagement in university students: A cross-national study. Journal of Cross-Cultural Psychology, 33(5), 464-481. https://doi.org/10.1177/0022022102033005003

Segura O. (2014). Agotamiento profesional: concepciones e implicaciones en la salud pública. Biomédica, 34(4), 535-545. https://doi.org/10.7705/biomedica.v34i4.2315

Su, J.C., So, M.J. and Yoon-Sok, C. (2017). The mediating effect of calling on the relationship between medical school students' academic burnout and empathy. Korean J Med Educ, 29(3), 165-173. https://doi.org/10.3946/kjme.2017.62

Tomaschewski-Barlem JG, Lunardi VL, Lunardi GL, Barlem ELD, Silveira RS, Vidal DAS. (2014). Burnout syndrome among undergraduate nursing students at a public university Rev. Latino-Am. Enfermagem, 22(6), 934-41. https://doi.org/10.1590/0104-1169.3254.2498

Wendy, L., Awa, M.P. and Walter, U. (2010). Burnout prevention: A review of intervention programs. Patient Education and Counseling, 78, 184-190. https://doi.org/10.1016/i.pec.2009.04.008

Wiklund P. (2016). The role of physical activity and exercise in obesity and weight management: Time for critical appraisal. Journal of Sport and Health Science, 5(2), 151-154. https://doi.org/10.1016/i.jshs.2016.04.001

Womble, M.N., Labbé, E.E., Shelley-Tremblay, J.F., Norrell, P. (2014). Regular Exercise Adoption: Psychosocial Factors Influencing College Students. Journal of Sport Behavior, 37(2), 203-219. https://doi.org/10.1037/e701842011-001 


\section{(c) $)(1) \Theta(9)$}

This work is licensed under a Attribution-NonCommercial-NoDerivatives 4.0 International (CC BY-NC-ND 4.0). 